\title{
Effect of soya protein on serum lipid profile and lipoprotein concentrations in patients undergoing hypercholesterolaemic haemodialysis
}

\author{
Shu-Tzu Chen ${ }^{1}$, Jiun-Rong Chen ${ }^{1}$, Chwei-Shiun Yang ${ }^{2}$, Sheng-Jeng Peng ${ }^{2}$ and Shyang-Hwa Ferng ${ }^{2 *}$ \\ ${ }^{1}$ Department of Nutrition and Health Sciences, Taipei Medical University, Taipei, Taiwan \\ ${ }^{2}$ Division of Nephrology, Cathay General Hospital, Taipei, Taiwan
}

(Received 26 August 2005 - Revised 11 October 2005 - Accepted 12 October 2005)

\begin{abstract}
Clinical trials have shown that soya protein reduces the concentrations of some atherogenic lipids in subjects with normal renal function. The present study examined the effects of soya protein on serum lipid concentrations and lipoprotein metabolism in patients on hypercholesterolaemic haemodialysis. Twenty-six hypercholesterolaemic (total cholesterol $\geq 6 \cdot 21 \mathrm{mmol} / \mathrm{l}$ ) patients on haemodialysis were studied in a randomized, double-blind, placebo-controlled clinical trial. After a 4-week run-in phase, the subjects were randomly assigned to two groups. Isolated soya protein or milk protein $30 \mathrm{~g}$ was consumed daily as a beverage at breakfast or post-dialysis for 12 weeks. Soya protein substitution resulted in significant reductions in total cholesterol (17.2 (SD 8.9)\%), LDL-cholesterol (15.3 (SD 12.5)\%), apo B (14.6 (SD 12.1)\%) and insulin $(23.8$ (SD 18.7) \%) concentrations. There were no significant changes in HDL-cholesterol or apo A-I. These results indicate that replacing part of the daily protein intake with soya protein has a beneficial effect on atherogenic lipids and favourably affects lipoprotein metabolism in hypercholesterolaemic patients undergoing haemodialysis.
\end{abstract}

Soya protein: Haemodialysis: Lipoproteins: Hypercholesterolaemia

Progressive renal failure is associated with abnormalities of lipid and lipoprotein metabolism (Attman et al. 1993). Patients on maintenance haemodialysis treatment have a higher prevalence of elevated blood cholesterol when compared with the general population (Ma et al. 1992; Kronenberg et al. 2003). The management of hypercholesterolaemia is one of the important therapeutic goals for patients on haemodialysis (Levey et al. 1998; Sarnak, 2003), and dietary therapy is an integral component of the treatment of hypercholesterolaemia. The National Cholesterol Educational Program Step I diet, which restricts fat ( $<30 \%$ total energy), is usually recommended as the initial treatment to lower the serum cholesterol level (National Cholesterol Educational Program, 1993). However, patients on haemodialysis have a number of other nutritional concerns, and it is difficult to reduce fat to less than $30 \%$ total energy intake in a usual haemodialysis diet.

A normally prescribed diet for the patient receiving maintenance haemodialysis contains a high level of protein $(>1.2 \mathrm{~g} / \mathrm{kg}$ per d; K/DOQI, 2000). Foods containing animal proteins are a major source of dietary fats and cholesterol, and this diet may be accompanied by other side-effects such as an increased blood cholesterol level and atherosclerosis (Kritchevsky, 1995). Research has shown that soya protein decreases serum cholesterol and enhances the hypocholesterolaemic effect of the National Cholesterol Educational Program Step I diet in hypercholesterolaemic individuals with normal renal function (Anderson et al. 1995; Baum et al. 1998; Sirtori et al. 1999; Teixeira et al. 2000), and in patients with nephrotic syndrome or diabetic nephropathy (D'Amico et al. 1992; Azadbakht et al. 2003; Teixeira et al. 2004). Our previous study demonstrated that soya protein improved the serum lipid profile in animals with renal failure (Chen et al. 2003).

Because of the limited data available, it is unclear whether soya protein has a clinically relevant and beneficial effect on plasma lipid management in patients on haemodialysis. The present study was therefore designed in order to examine the effects of consuming soya protein as a part of the dietary protein on serum lipid profile and apo and lipoprotein metabolism in hypercholesterolaemic patients on haemodialysis.

\section{Subjects and methods}

Subjects

Non-diabetic patients with hypercholesterolaemia who were on maintenance haemodialysis were recruited from the Haemodialysis Center of Cathay General Hospital, Taipei, Taiwan. Subjects were screened for an initial fasting plasma total cholesterol (TC) concentration of $6 \cdot 21 \mathrm{mmol} / \mathrm{l}$ $(240 \mathrm{mg} / \mathrm{dl})$ or above, and a fasting plasma triacylglycerol concentration of less than $2.25 \mathrm{mmol} / 1(200 \mathrm{mg} / \mathrm{dl})$. In addition, no lipid-lowering therapy was to have been taken within the 
past month, and the patients were to have been on regular thrice-weekly maintenance haemodialysis for at least 1 year, to have no intercurrent illness and to show a normal fasting plasma glucose concentration. Exclusion criteria included the presence of liver disease, thyroid disease, severe hypertension or cancer, or the use of any medication known to affect lipid concentration. Subjects who failed to comply with the diet or had a weight variation of $3 \mathrm{~kg}$ or more during the study were excluded from the final analysis. The protocol was approved by the Human Investigation Review Committee of Cathay General Hospital and Taipei Medical University. All subjects were informed about the study and provided written informed consent before they began the study.

Of the thirty-five patients screened, twenty-nine gave their informed consent and twenty-seven subjects completed the study. Two withdrew from the study because of gastrointestinal problems (constipation and gastrointestinal upset). One subject who failed to consume the assigned dose of protein $(1.2 \mathrm{~g} / \mathrm{kg}$ per $\mathrm{d})$, as assessed by the dietitian, was excluded from the statistical analyses. Twenty-six subjects completed the study and were included in the statistical analyses.

\section{Study design and diet}

During a 4-week run-in phase, all the subjects followed a usual haemodialysis diet (35\% fat, $1.2 \mathrm{~g} / \mathrm{kg}$ per d protein and $134-147 \mathrm{~kJ} / \mathrm{kg}$ per $\mathrm{d}$ energy). A registered dietitian instructed the subjects on this diet and counselled them about their individual needs for protein, fat and energy.

After the run-in phase, baseline blood samples were drawn, and subjects whose TC concentration was still $6.21 \mathrm{mmol} / \mathrm{l}$ or above were randomly assigned to one of two dietary treatment groups that provided isolated soya protein (ISP) or milk protein (control group). For 12 weeks, the two groups continued to consume the usual haemodialysis diet and were also asked to consume one $30 \mathrm{~g}$ packet of ISP (SUPRO 660; Protein Technologies International, St Louis, MO, USA) or one $30 \mathrm{~g}$ packet of milk protein (P93; Sentosa, BV, Holland) per d at breakfast (on non-dialysis days) or post-dialysis (on dialysis days). Dietary counselling was given individually with the goal of making a dietary adjustment to incorporate the test protein into the subjects' diet without causing weight gain or changes in protein or energy intake. This requirement was reinforced at the clinic visits and was monitored during the study by reviewing the dietary recalls. Clinic visits were conducted every dialysis day.

At each clinic visit, study protein was delivered, and any packets left over from the previous visit were collected to determine compliance. A $24 \mathrm{~h}$ dietary recall was performed in both groups for $3 \mathrm{~d}$ every 4 weeks. The $3 \mathrm{~d}$ included a dialysis day, a non-dialysis day and a Sunday. Compliance with dietary protein intake was measured in two ways: (1) by a $24 \mathrm{~h}$ dietary recall; (2) by calculating the protein equivalent of $\mathrm{N}$ appearance (PNA) from determining the appearance of urea N. ISP was fortified with Ca (calcium lactate) to amounts comparable with those found in milk protein. The test products contained a mixture of protein, carbohydrate, fat and $\mathrm{Ca}$ in sealed packets (Table 1). It was suggested that the test product be mixed with $200 \mathrm{ml}$ water or soup, and shakers were provided for mixing purposes.
Table 1. Contents of the test products (per package)

\begin{tabular}{lcc}
\hline Variable & Milk protein & Isolated soya protein \\
\hline Protein $(\mathrm{g})$ & $30 \cdot 7$ & $30 \cdot 7$ \\
Energy $(\mathrm{kJ})$ & 154.5 & 154.6 \\
Fat $(\mathrm{g})$ & $8 \cdot 6$ & $8 \cdot 7$ \\
Carbohydrate $(\mathrm{g})$ & $42 \cdot 3$ & $42 \cdot 1$ \\
Ca (mg) & 411 & 408 \\
Total isoflavones $(\mathrm{mg})$ & $\mathrm{ND}$ & $36 \cdot 3$ \\
\hline
\end{tabular}

ND, not detectable.

For details of diets and procedures, see this page.

Throughout the study, all subjects were asked to maintain their oedema-free body weight and not to take any nutritional supplements for the duration of the investigation. Subjects, study staff and laboratory technicians were blinded to the treatment assignments during the trial period.

\section{Data collection}

Blood samples were collected every 4 weeks after the subjects had fasted for $10-12 \mathrm{~h}$. The blood was collected in tubes with heparin and was separated by centrifugation at $2000 \mathrm{~g}$ for 15 min at $4^{\circ} \mathrm{C}$. Laboratory assessments included fasting serum lipids (TC, triacylglycerol, HDL-cholesterol (HDL-C), LDLcholesterol (LDL-C), apo A-I, apo B), insulin, glucose, urea N, uric acid, $\mathrm{Ca}, \mathrm{PO}_{4}$ and albumin. Body weight was measured every dialysis day; the oedema-free body weight was obtained post-dialysis and was used to calculate the BMI. Daily nutrient intakes were estimated from the $24 \mathrm{~h}$ dietary recall and analysed using standard food composition tables.

\section{Laboratory analyses}

Serum TC was measured enzymatically, and HDL-C and LDL$\mathrm{C}$ were quantified by the homogenous assay method using an automated analyser (AU2700 automated chemistry analyzer; Olympus, Tokyo, Japan). Serum apo A-I and apo B concentrations were measured by immunoturbidimetry with an automated analyser (Integra 800; Roche, Mannheim, Germany). Serum insulin concentration was measured by microparticle enzyme immunoassay using an Abbott AxSYM analyzer (Abbott Laboratories, Abbott Park, IL, USA). All serum nutritional parameters were determined using an automated analyser (Olympus AU2700). The normalized PNA was calculated using a two-blood urea N, single-pool, variable-volume model (K/DOQI, 2000). Adequacy of haemodialysis was monitored using the urea kinetic model (K/DOQI, 2000).

\section{Statistical analysis}

Statistical analyses were performed using the SAS software (version 8.2; SAS Institute, Inc., Cary, NC, USA). All statistical tests were two-tailed, and significance for all analyses was set at $P<0 \cdot 05$. Changes from the baseline within each group were evaluated using the paired $t$ test, and differences at each time point were compared using one-way ANOVA and Fisher's least significant difference test. Between-group differences were tested using the Student's $t$ test. 
Table 2. Baseline characteristics of subjects (Means and standard deviations)

\begin{tabular}{|c|c|c|c|c|}
\hline & \multicolumn{2}{|c|}{$\begin{array}{l}\text { Milk protein } \\
\quad(n 13)\end{array}$} & \multicolumn{2}{|c|}{$\begin{array}{l}\text { Isolated soya } \\
\text { protein }(n 13)\end{array}$} \\
\hline & Mean & SD & Mean & SD \\
\hline Age (years) & $58 \cdot 1$ & $12 \cdot 5$ & $59 \cdot 1$ & $11 \cdot 1$ \\
\hline $\mathrm{BMI}^{*}\left(\mathrm{~kg} / \mathrm{m}^{2}\right)$ & $22 \cdot 6$ & $2 \cdot 7$ & 23.5 & 2.9 \\
\hline Years of dialysis & $4 \cdot 1$ & 3.9 & 5.9 & $3 \cdot 8$ \\
\hline Men $(n)$ & \multicolumn{2}{|c|}{9} & \multicolumn{2}{|c|}{10} \\
\hline Women $(n)$ & \multicolumn{2}{|c|}{4} & \multicolumn{2}{|c|}{3} \\
\hline
\end{tabular}

*BMI was calculated from the oedema-free body weight and height.

There were no significant differences between the groups in terms of BMI, age and years of dialysis.

For details of subjects and procedures, see p. 366.

\section{Results}

Subject characteristics at baseline are shown in Table 2. The body weights of the subjects remained stable in each group throughout the study. No significant differences were found in nutrient intake, serum nutritional parameters and adequacy of haemodialysis between the two groups, and no significant changes between the baseline and the end of the study were noted within each group except for cholesterol and saturated fat intake (Table 3).

Plasma TC concentrations measured at baseline and weeks 4, 8 and 12 of the study are shown in Table 4 . The TC of the ISP group was significantly lower than that of the milk group at week 12. The time-by-treatment interaction was significant in the ISP group but not in the milk group. In addition, the ISP group had a greater decrease in TC from baseline than the milk group $(-17.2$ (SD 8.9$) \% \quad v . \quad-4.6 \quad$ (SD 12.8)\%; $P=0.03)$. There were no significant changes in triacylglycerol concentration in the two groups (Table 5).

Lipoprotein and apo concentrations are shown in Table 5. LDL-C concentration was significantly reduced in the ISP group at week 12 compared with the baseline, but no significant difference was seen between the two groups. However, the LDL-C concentration decreased more in the ISP group than in the milk group ( $-15 \cdot 3$ (SD 12.5)\% v. 1.0 (SD 20.4)\%; $P<0.05$ ), and there was no significant change in LDL-C in the milk group at the end of the study. Non-HDL cholesterol,

Table 3. Nutrient intake and serum nutritional parameters at the baseline and week 12 (Means and standard deviations)

\begin{tabular}{|c|c|c|c|c|c|c|c|c|}
\hline & \multicolumn{4}{|c|}{ Milk protein ( $n$ 13) } & \multicolumn{4}{|c|}{ Isolated soya protein ( $n$ 13) } \\
\hline & \multicolumn{2}{|c|}{ Baseline } & \multicolumn{2}{|c|}{ Week 12} & \multicolumn{2}{|c|}{ Baseline } & \multicolumn{2}{|c|}{ Week 12} \\
\hline & Mean & SD & Mean & SD & Mean & SD & Mean & SD \\
\hline Energy (kJ/kg) & $134 \cdot 4$ & $13 \cdot 4$ & $134 \cdot 0$ & 7.9 & 133.6 & $6 \cdot 7$ & $135 \cdot 2$ & 0.0 \\
\hline Protein $(\mathrm{g} / \mathrm{kg})$ & $1 \cdot 2$ & $0 \cdot 1$ & $1 \cdot 2$ & $0 \cdot 1$ & $1 \cdot 2$ & 0.1 & $1 \cdot 2$ & 0.2 \\
\hline Carbohydrate (\% energy) & $48 \cdot 2$ & $2 \cdot 3$ & $52 \cdot 1$ & $6 \cdot 3$ & $48 \cdot 8$ & $7 \cdot 0$ & $51 \cdot 6$ & $3 \cdot 8$ \\
\hline Fat (\% energy) & $36 \cdot 9$ & $4 \cdot 3$ & $35 \cdot 0$ & $3 \cdot 1$ & $36 \cdot 8$ & $2 \cdot 1$ & $35 \cdot 4$ & $5 \cdot 2$ \\
\hline Saturated ( $\%$ energy) & $13 \cdot 5$ & $2 \cdot 8$ & $7 \cdot 1^{*}$ & $2 \cdot 3$ & $13 \cdot 6$ & $2 \cdot 7$ & $6 \cdot 9^{*}$ & $1 \cdot 4$ \\
\hline Cholesterol (mg/d) & 387 & 85 & $191^{*}$ & 56 & 390 & 92 & $189^{\star}$ & 67 \\
\hline Fibre (g/d) & $11 \cdot 1$ & $2 \cdot 7$ & $11 \cdot 4$ & $3 \cdot 8$ & $10 \cdot 8$ & 3.4 & $11 \cdot 3$ & 2.9 \\
\hline nPNA (g/kg per d) & $1 \cdot 3$ & 0.3 & 1.4 & 0.4 & 1.4 & 0.4 & 1.5 & 0.2 \\
\hline Albumin (g/l) & 41 & 5 & 42 & 4 & 42 & 2 & 41 & 3 \\
\hline Glucose (mmol/l) & $5 \cdot 7$ & 0.7 & $5 \cdot 8$ & 0.5 & $5 \cdot 8$ & 0.6 & $5 \cdot 8$ & 0.5 \\
\hline $\mathrm{Ca}(\mathrm{mmol} / \mathrm{l})$ & $2 \cdot 4$ & 0.2 & $2 \cdot 4$ & 0.2 & $2 \cdot 4$ & 0.2 & $2 \cdot 3$ & 0.3 \\
\hline $\mathrm{PO}_{4}(\mathrm{mmol} / \mathrm{l})$ & $1 \cdot 8$ & 0.4 & $1 \cdot 7$ & 0.4 & 1.8 & 0.4 & 1.8 & 0.5 \\
\hline $\mathrm{Kt} / \mathrm{V}^{2}$ & 1.9 & 0.3 & $1 \cdot 8$ & 0.3 & 1.9 & 0.3 & $1 \cdot 8$ & 0.3 \\
\hline
\end{tabular}

Nutrient intake calculated from $3 \mathrm{~d}$ of $24 \mathrm{~h}$ dietary recall.

nPNA, normalized protein equivalent of nitrogen appearance calculated by using two-blood urea N, single-pool, variable-volume mode.

$\mathrm{Kt} / \mathrm{V}$, urea kinetic model calculated from the natural log formula.

Mean values were significantly different from the baseline: ${ }^{*} P<0.05$.

For details of diets and procedures, see p. 367.

Table 4. Plasma total cholesterol concentrations of the study subjects at four time points during the study (Means and standard deviations)

\begin{tabular}{|c|c|c|c|c|c|c|c|c|}
\hline \multirow[b]{2}{*}{ Total cholesterol $(\mathrm{mmol} / \mathrm{l})$} & \multicolumn{2}{|c|}{ Baseline } & \multicolumn{2}{|c|}{ Week 4} & \multicolumn{2}{|c|}{ Week 8} & \multicolumn{2}{|c|}{ Week 12} \\
\hline & Mean & SD & Mean & SD & Mean & SD & Mean & SD \\
\hline Milk protein $(n 13)$ & $6 \cdot 91^{a}$ & 0.47 & $6 \cdot 20^{\mathrm{b}}$ & 0.59 & $6 \cdot 27^{\mathrm{b}}$ & 0.69 & $6.59^{a, b}$ & 0.97 \\
\hline Isolated soya protein ( $n 13)$ & $7 \cdot 02^{a}$ & 0.90 & $6 \cdot 21^{\mathrm{b}}$ & 1.01 & $5 \cdot 93^{b}$ & 0.97 & $5 \cdot 76^{\mathrm{b}, *}$ & 0.89 \\
\hline
\end{tabular}

a,b Values within the same row with unlike superscript letters were significantly different $(P<0.05)$.

* Significantly different from the milk protein group $(P<0.05)$.

For details of subjects and procedures, see p. 366. 
Table 5. Triacylglycerol, insulin, lipoprotein and apo concentrations of subjects at baseline and week 12 (Means and standard deviations)

\begin{tabular}{|c|c|c|c|c|c|c|c|c|}
\hline & \multicolumn{4}{|c|}{ Milk protein ( $n$ 13) } & \multicolumn{4}{|c|}{ Isolated soya protein (n 13) } \\
\hline & \multicolumn{2}{|c|}{ Baseline } & \multicolumn{2}{|c|}{ Week 12} & \multicolumn{2}{|c|}{ Baseline } & \multicolumn{2}{|c|}{ Week 12} \\
\hline & Mean & SD & Mean & SD & Mean & SD & Mean & SD \\
\hline Triacylglycerol (mmol/l) & 1.97 & 0.27 & 1.88 & 0.29 & $2 \cdot 00$ & 0.57 & 1.77 & 0.38 \\
\hline $\mathrm{HDL}-\mathrm{C}(\mathrm{mmol} / \mathrm{l})$ & 0.95 & $0 \cdot 18$ & 0.98 & 0.13 & 1.00 & 0.22 & 1.03 & 0.19 \\
\hline LDL-C (mmol/l) & 4.09 & 0.98 & 3.98 & 0.61 & $4 \cdot 31$ & 1.03 & 3.56@ & 0.78 \\
\hline Non-HDL cholesterol (mmol/l) & $6 \cdot 00$ & 0.49 & $5 \cdot 60$ & 1.00 & $6 \cdot 02$ & 0.95 & 4.72@\# & 0.85 \\
\hline $\mathrm{TC} / \mathrm{HDL}-\mathrm{C}$ & 7.55 & 1.66 & $6 \cdot 85$ & $1 \cdot 38$ & $7 \cdot 37$ & $2 \cdot 00$ & 5.69@\# & 0.96 \\
\hline LDL-C/HDL-C & $4 \cdot 33$ & 0.83 & $4 \cdot 11$ & 0.63 & 4.50 & 1.49 & 3.48@\# & 0.63 \\
\hline Apo A-I (g/l) & $12 \cdot 7$ & $1 \cdot 7$ & $12 \cdot 7$ & $1 \cdot 7$ & $12 \cdot 7$ & $1 \cdot 8$ & $13 \cdot 0$ & $1 \cdot 7$ \\
\hline Apo B $(g / l)$ & $12 \cdot 5$ & $1 \cdot 3$ & $12 \cdot 0$ & $1 \cdot 3$ & $12 \cdot 3$ & $1 \cdot 2$ & 10.4@\# & $1 \cdot 6$ \\
\hline Insulin (pmol/l) & $100 \cdot 8$ & $58 \cdot 4$ & $99 \cdot 4$ & $40 \cdot 3$ & $102 \cdot 2$ & 54.9 & 66.8@\# & 35.5 \\
\hline
\end{tabular}

HDL-C, HDL-cholesterol; LDL-C, LDL-cholesterol; TC, total cholesterol.

@ Significantly different from baseline.

\# Significantly different from the milk protein group.

For details of subjects and procedures, see p. 366

apo B and the ratio of TC to HDL-C in the ISP group fell significantly and were significantly lower than those of the milk group at week 12. There were no significant changes in HDL$\mathrm{C}$ or apo A-I in the two groups. The insulin concentration of the ISP group had significantly decreased and was significantly lower than that in the milk group at week 12 (Table 5).

\section{Discussion}

The results from the present study showed that soya protein had a beneficial effect on serum lipid profile in hypercholesterolaemic patients undergoing haemodialysis. The replacement of $30 \mathrm{~g}$ daily protein intake with soya protein in a usual haemodialysis diet for 12 weeks produced a significant decrease in TC, as well as in LDL-C, non-HDL cholesterol and apo B concentration, without changing the HDL-C level at the end of the study, whereas milk protein had no such effect.

Taking into account the lower intake of dietary saturated fat and cholesterol during the study period, we had anticipated this reduction in TC for both groups (Ramsay et al. 1991). The milk protein group had, however, a significantly lower TC level only in the first 8 weeks and did not show significant difference at the end of the study. The reverse increase in TC concentration after week 4 in the milk protein group may have been due to casein being used as the major protein component in this group. Casein has been found to be more hypercholesterolaemic than soya protein (Terpstra et al. 1981; Kurowska \& Carroll, 1990). Furthermore, the time-by-treatment interaction was significant in the soya protein group, and there was a significant reduction in TC from baseline compared with the milk protein group. These findings show that soya protein has a hypocholesterolic effect in hypercholesterolaemic patients on haemodialysis and that it enhances the cholesterol-lowering effect of a low-cholesterol, low-saturated fat diet.

LDL-C concentration also decreased in the milk group, but this decrease was not significant. The change of LDL-C concentration in the milk protein group could be attributed to a reduction in saturated fat and cholesterol. Gardner et al. (2001) similarly showed an unexpected decreased effect of milk protein supplementation on TC and LDL-C in hypercholesterolaemic postmenopausal women. Because there were no significant changes in diet or body weight, Gardner et al. suggested that the decreased effect might have been due to other factors related to participation in the study. Tonstad et al. (2002) reported that decreases in LDL-C in their casein groups were greater than expected, possibly because of seasonal or dietary adaptation. In the present study, there was a significant decrease in the LDL-C level of the soya protein group from baseline, and levels were significantly reduced to a greater extent in the soya group than in the milk group.

The clinical significance of ingesting soya protein on HDLC concentration remains controversial (Potter et al. 1993; Anderson et al. 1995; Kurowska et al. 1997; Baum et al. 1998; Teixeira et al. 2000; Tonstad et al. 2002; Azadbakht et al. 2003). No significant changes were observed in the current study in HDL-C and apo A-I concentrations, which differs from the previous findings for nephrotic syndrome. D'Amico et al. (1992) reported that a soya protein diet not only significantly decreased TC and LDL-C, but also significantly reduced HDL-C and apo A concentrations in patients with nephrotic syndrome. The difference between our current findings in patients receiving haemodialysis and the previous findings in nephrotic syndrome could be due to the fact that the diets used in nephrotic patients contain high levels of PUFA.

Studies have shown decreased effects of soya protein on the apo B concentration (Potter et al. 1993; Teixeira et al. 2000). In the present study, the decline in apo B paralleled the decline in LDL-C, which is consistent with the findings of Potter et al. (1993). Reductions in non-HDL cholesterol concentration with soya protein consumption have also been shown by several clinical trials (Baum et al. 1998; Potter et al. 1998; Teixeira et al. 2000). Significant decreases in apo B and non-HDL cholesterol concentrations in the soya group may indicate an antiatherogenic effect of soya protein in hypercholesterolaemic patients on haemodialysis. Recent data from a cohort of 525 haemodialysis patients demonstrated that non-HDL cholesterol was a significant and independent predictor of CVD mortality in haemodialysis patients (Nishizawa et al. 2003). Apo B is also an independent factor associated with 
morbidity from myocardial infarction in haemodialysis patients (Koch et al. 1997).

The mechanism of how lipid metabolism is influenced by soya protein has not been fully established. Studies have indicated that soya protein enhances faecal steroid excretion, affects the hepatic metabolism of cholesterol, alters cholesterol- $7 \alpha$ - hydroxylase, HMGCoA reductase and apo B receptor activity (Potter, 1995), and increases the expression of LDL receptors (Baum et al. 1998), which are associated with an increased clearance of cholesterol; these may all be considered to be possible mechanisms. In a recent meta-analysis, isoflavones contained in soya protein were linked to an improvement in plasma lipid levels (Zhuo et al. 2004). The long-term intake of soya protein containing isoflavones can increase HDL-C concentration (Zhan \& Ho, 2005). Although only small amounts of isoflavones ( $36 \mathrm{mg}$ per package) were contained in the test protein, isoflavones may accumulate in haemodialysis patients owing to a lack of renal excretion and their unavailability for dialysis (Fanti et al. 1999). Thus, the favourable effect of soya protein substitution on lipid profile in the present study could be partially attributable to the isoflavones contained in soya protein.

Patients with end-stage renal disease are known to have insulin resistance (DeFronzo et al. 1981). In rats, feeding soya protein has been shown to be associated with a lower insulin secretion and a maintenance of normal serum insulin concentrations compared with feeding a casein diet (Ascencio et al. 2004). In the present study, serum insulin concentrations in the ISP group were significantly lower than those in the milk group. These data indicate that insulin may play an important role in the effect of soya protein on lipoprotein metabolism. Mechanisms responsible for how soya protein alters insulin secretion and insulin concentration are still being explored. An animal study demonstrated that soya protein increased the expression of the insulin receptor gene (Iritani et al. 1997), which may be a possible mechanism explaining the beneficial effect of soya protein on insulin resistance.

The estimation of dietary protein intake from the $24 \mathrm{~h}$ dietary recall and normalized PNA confirmed that the test proteins consumed indeed substituted for other animal proteins. Body weight remained stable in each group throughout the study, suggesting good compliance with the dietary prescription. There were no significant differences in nutritional parameters between the two groups at the end of the study, indicating that substituting soya protein $(30 \mathrm{~g} / \mathrm{d})$ for animal protein can maintain the nutritional status of haemodialysis patients.

Although the present observations demonstrate the efficacy of 12 weeks of soya protein consumption in hypercholesterolaemic patients undergoing haemodialysis, more studies are required to examine long-term compliance and effects, including adverse effects. Another limitation of this study is its lack of proteomic investigation of the test protein (SUPRO 660): a proteomic investigation has shown a possible association between the protein components (i.e. the $7 \mathrm{~S}$ globulin) and the variability in lipid response to soya protein intake (Gianazza et al. 2003).

Few data are, however, available for defining the effects of soya protein on lipid metabolism in haemodialysis patients. The present study shows that the TC, LDL-C, non-HDL cholesterol and apo B concentrations of hypercholesterolaemic patients undergoing haemodialysis significantly decreased with soya protein administration. In conclusion, our findings indicate that substituting a part of the daily protein with soya protein could be a good alternative to a normal haemodialysis diet, while helping to treat hypercholesterolaemia. Furthermore, patients on maintenance haemodialysis were able to include $30 \mathrm{~g}$ soya protein in their diet without changing their nutritional status.

\section{Acknowledgements}

This work was supported by a grant (94CGH-TMU-05) from the Cathay General Hospital Research Program. We thank all the participants in this study and the staff of the Haemodialysis Center at Cathay General Hospital.

\section{References}

Anderson JW, Johnstone BM \& Cook-Newell ME (1995) Meta-analysis of the effects of soy protein intake on serum lipids. $N$ Engl $J$ Med 333, 276-282.

Ascencio C, Torres N, Isoard-Acosta F, Gomez-Perez FJ, HernandezPando R \& Tovar AR (2004) Soy protein affects serum insulin and hepatic SREBP-1 mRNA and reduces fatty liver in rats. $J$ Nutr 134, $522-529$.

Attman PO, Samuelsson O \& Alaupovic P (1993) Lipoprotein metabolism and renal failure. Am J Kidney Dis 21, 573-592.

Azadbakht L, Shakerhosseini R, Atabak S, Jamshidian M, Mehrabi Y \& Esmaill-Zadeh A (2003) Beneficiary effect of dietary soy protein on lowering plasma levels of lipid and improving kidney function in type II diabetes with nephropathy. Eur J Clin Nutr 57, $1292-1294$.

Baum JA, Teng H, Erdman JW Jr, et al. (1998) Long-term intake of soy protein improves blood lipid profiles and increases mononuclear cell low-density-lipoprotein receptor messenger RNA in hypercholesterolemic, postmenopausal women. Am J Clin Nutr 68, 545-551.

Chen ST, Peng SJ \& Chen JR (2003) Effects of dietary protein on renal function and lipid metabolism in five-sixths nephrectomized rats. Br J Nutr 89, 491-497.

D’Amico G, Gentile MG, Manna G, Fellin G, Ciceri R, Cofano F, Petrinic C, Lavarda F, Perolini S \& Porrini M (1992) Effect of vegetarian soy diet on hyperlipidaemia in nephrotic syndrome. Lancet 339, $1131-1134$.

DeFronzo RA, Alvestrand A, Smith D, Hendler R, Hendler E \& Wahren J (1981) Insulin resistance in uremia. J Clin Invest 67, 563-568.

Fanti P, Sawaya BP, Custer LJ \& Fanke AA (1999) Serum levels and metabolic clearance of the isoflavones genistein and daidzein in hemodialysis patients. J Am Soc Nephrol 10, 864-871.

Gardner CD, Newell KA, Cherin R \& Haskell WL (2001) The effect of soy protein with or without isoflavones relative to milk protein on plasma lipids in hypercholesterolemic postmenopausal women. Am J Clin Nutr 73, 728-735.

Gianazza E, Eberini I, Arnoldi A, Wait R \& Sirtori CR (2003) A proteomic investigation of isolated soy protein with variable effects in experimental and clinical studies. J Nutr 133, 9-14.

Iritani N, Sugimoto T, Fukuda H, Komiya M \& Ikeda H (1997) Dietary soybean protein increases insulin receptor gene expression in Wistar fatty rats when dietary polyunsaturated fatty acid level is low. J Nutr 127, 1077-1083.

K/DOQI (National Kidney Foundation) (2000) Clinical practice guidelines for nutrition in chronic renal failure. Am J Kidney Dis 35, S1-S140. 
Koch M, Kutkuhn B, Trenkwalder E, Bach D, Grabensee B, Dieplinger H \& Kronenberg F (1997) Apolipoprotein B, fibrinogen, HDL cholesterol, and apolipoprotein (a) phenotypes predict coronary artery disease in hemodialysis patients. J Am Soc Nephrol 8, $1889-1898$.

Kritchevsky D (1995) Dietary protein, cholesterol and atherosclerosis: a review of the early history. J Nutr 125, 589S-593S.

Kronenberg F, Lingenhel A, Neyer U, Lhotta K, Konig P, Auinger M, Wiesholzer M, Andersson H \& Dieplinger H (2003) Prevalence of dyslipidemic risk factors in hemodialysis and CAPD patients. Kidney Int 63, Suppl 84, S113-S116.

Kurowska EM \& Carroll KK (1990) Essential amino acids in relation to hypercholesterolemia induced in rabbits by dietary casein. $J$ Nutr 120, 831-836.

Kurowska EM, Jordan J, Spence JD, Wetmore S, Piche LA, Radzikowski M, Dandona P \& Carroll KK (1997) Effects of substituting dietary soybean protein and oil for milk protein and fat in subjects with hypercholesterolemia. Clin Invest Med 20, 162-170.

Levey AS, Beto JA, Coronado BE, et al. (1998) Controlling the epidemic of cardiovascular disease in chronic renal disease: what do we know? What do we need to learn? Where do we go from here? National Kidney Foundation Task Force on Cardiovascular Disease. Am J Kidney Dis 32, 853-906.

Ma KW, Greene EL \& Raij L (1992) Cardiovascular risk factors in chronic renal failure and hemodialysis populations. Am J Kidney Dis 19, 505-513.

National Cholesterol Education Program (1993) Summary of the second report of the National Cholesterol Education Program (NCEP) Expert Panel on Detection, Evaluation, and Treatment of High Blood Cholesterol in Adults (Adult Treatment Panel II). JAMA 269, 3015-3023.

Nishizawa Y, Shoji T, Kakiya R, Tsujimoto Y, Tabata T, Ishimura E, Nakatani T, Miki T \& Inaba M (2003) Non-high-density lipoprotein cholesterol (non-HDL-C) as a predictor of cardiovascular mortality in patients with end-stage renal disease. Kidney Int Suppl S117-S120.

Potter SM (1995) Overview of proposed mechanisms of the hypocholesterolemic effect of soy. J Nutr 125, 606S-611S.

Potter SM, Bakhit RM, Essex-Sorlie DL, Weingartner KE, Chapman KM, Nelson RA, Prabhudesai M, Savage WD, Nelson AI
\& Winter LW (1993) Depression of plasma cholesterol in men by consumption of baked products containing soy protein. Am J Clin Nutr 58, 501-506.

Potter SM, Baum JA, Teng H, Stillman RJ, Shay NF \& Erdman JW Jr (1998) Soy protein and isoflavones: their effects on blood lipids and bone density in postmenopausal women. Am J Clin Nutr 68, 1375S-1379S

Ramsay LE, Yeo WW \& Jackson PR (1991) Dietary reduction of serum cholesterol concentration: time to think again. $B M J \mathbf{3 0 3}$, 953-957.

Sarnak MJ (2003) Cardiovascular complications in chronic kidney disease. Am J Kidney Dis 41, 11-17.

Sirtori CR, Pazzucconi F, Colombo L, Battistin P, Bondioli A \& Descheemaeker K (1999) Double-blind study of the addition of high-protein soya milk v. cows' milk to the diet of patients with severe hypercholesterolaemia and resistance to or intolerance of statins. Br J Nutr 82, 91-96.

Teixeira SR, Potter SM, Weigel R, Hannum S, Erdman JW Jr \& Hasler CM (2000) Effects of feeding 4 levels of soy protein for 3 and $6 \mathrm{wk}$ on blood lipids and apolipoproteins in moderately hypercholesterolemic men. Am J Clin Nutr 71, 1077-1084.

Teixeira SR, Tappenden KA, Carson L, Jones R, Prabhudesai M, Marshall WP \& Erdman JW Jr (2004) Isolated soy protein consumption reduces urinary albumin excretion and improves the serum lipid profile in men with type 2 diabetes mellitus and nephropathy. J Nutr 134, 1874-1880.

Terpstra AH, Harkes L \& van der Veen FH (1981) The effect of different proportions of casein in semipurified diets on the concentration of serum cholesterol and the lipoprotein composition in rabbits. Lipids 16, 114-119.

Tonstad S, Smerud K \& Hoie L (2002) A comparison of the effects of 2 doses of soy protein or casein on serum lipids, serum lipoproteins, and plasma total homocysteine in hypercholesterolemic subjects. Am J Clin Nutr 76, 78-84.

Zhan S \& Ho SC (2005) Meta-analysis of the effects of soy protein containing isoflavones on the lipid profile. Am J Clin Nutr 81, 397-408.

Zhuo XG, Melby MK \& Watanabe S (2004) Soy isoflavones intake lowers serum LDL cholesterol: A metaanalysis of 8 randomized controlled trials in humans. $J$ Nutr 134, 2395-2400. 